\title{
STALIN'S NIÑOS
}

\author{
Educating Spanish Civil War Refugee Children \\ in the Soviet Union, 1937-1951
}

Stalin's Niños examines how the Soviet Union raised and educated nearly three thousand child refugees of the Spanish Civil War. An analysis of the archival record and numerous letters, oral histories, and memoirs uncovers a little-known story that describes the Soviet transformation of children into future builders of communism and reveals the educational techniques shared with other modern states. Classroom education taught patriotism for the two homelands and the importance of emulating Spanish and Soviet heroes, scientists, soldiers, and artists. Extra-curricular clubs and activities reinforced classroom experiences and helped discipline the mind, body, and behaviours. Adult mentors, like the heroes studied in the classroom, provided models to emulate and became the tangible expression of the ideal Spaniard and Soviet. The Basque and Spanish children thus were transformed into hybrid Hispano-Soviets fully engaged with their native language, culture, and traditions while also imbued with Russian language and culture and Soviet ideals of hard work, comradery, internationalism, and sacrifice for ideals and others.

Throughout their fourteen-year existence and even during the horrific relocation to the Soviet interior during the Second World War, the twenty-two Soviet boarding schools designed specifically for the Spanish refugee children and better provisioned than those for Soviet children - transformed displaced niños into Red Army heroes, award-winning Soviet athletes and artists, successful educators and workers, and in some cases valuable resources helping to rebuild Cuba after the revolution. Stalin's Niños also sheds new light on the education of non-Russian Soviet and international students and the process of constructing a supranational Soviet identity.

KARL D. QUALLS is the John B. Parsons Chair in Liberal Arts and Sciences and a professor of History at Dickinson College. 

KARL D. QUALLS

\section{STALIN'S NIÑOS}

Educating Spanish Civil War Refugee Children in the Soviet Union, 1937-1951

UNIVERSITY OF TORONTO PRESS

Toronto Buffalo London 
(C) University of Toronto Press 2020

Toronto Buffalo London

utorontopress.com

Printed in Canada

ISBN 978-1-4875-0358-1 (cloth) ISBN 978-1-4875-1829-5 (EPUB)

ISBN 978-1-4875-2275-9 (paper) ISBN 978-1-4875-1828-8 (PDF)

\section{Library and Archives Canada Cataloguing in Publication}

Title: Stalin's niños: Educating Spanish Civil War refugee children in the Soviet Union, 1937-1951 / Karl D. Qualls.

Names: Qualls, Karl D., author.

Description: Includes bibliographical references and index.

Identifiers: Canadiana (print) 20190206063 | Canadiana (ebook)

20190206152 | ISBN 9781487522759 (softcover) | ISBN 9781487503581

(hardcover) | ISBN 9781487518295 (EPUB) | ISBN 9781487518288 (PDF)

Subjects: LCSH: Refugee children - Education - Soviet Union. | LCSH:

Refugee children - Soviet Union - Social conditions. | LCSH: Refugee

children - Spain - Social conditions. | LCSH: Spain - History - Civil

War, 1936-1939 - Refugees - Education - Soviet Union. | LCSH: Spain -

History - Civil War, 1936-1939 - Refugees - Soviet Union - Social

conditions. | LCSH: Communist education - Soviet Union.

Classification: LCC LA831.8.Q35 2020 | DDC 371.826/9140947-dc23

University of Toronto Press acknowledges the financial assistance to its publishing program of the Canada Council for the Arts and the Ontario Arts Council, an agency of the Government of Ontario.

\section{Canada Council for the Arts}

Funded by the Government of Canada

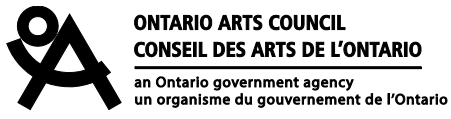


To my parents, Samuel and Marilyn 
